\title{
Isolation and characterization of polymorphic microsatellite markers for peacock wrasse (Symphodus tinca)
}

\author{
J. A. GALARZA, *J. CARRERAS-CARBONELL,†E. MACPHERSON,† G. F. TURNER*and C. RICO \\ *Department of Biological Sciences, University of Hull, HU6 7RX, UK, †Centre d’Estudis Avançats de Blanes (CSIC), Carrer d’accés \\ a la Cala Sant Francesc, núm.14, 17300 Blanes, Catalunya, Spain, †Estación Biológica Doñana (CSIC), Av. Ma. Luisa S/N, 41013 \\ Sevilla, Spain
}

\begin{abstract}
Eight polymorphic microsatellite loci were isolated and characterized for the peacock wrasse (Symphodus tinca), a labrid fish inhabiting the Mediterranean and Black seas. Characterization of 35 individuals from the western Mediterranean indicated a relatively high allelic diversity (mean $=12.4$, range 9-17), and observed heterozygosity ranging from 0.65 to 0.91 . We found no evidence of linkage disequilibrium between pairs of loci. Two loci showed significant departure from Hardy-Weinberg equilibrium. These polymorphic markers can be useful in most basic population genetic applications.
\end{abstract}

Keywords: enrichment, microsatellites, Symphodus tinca, wrasse

The peacock wrasse (Symphodus tinca) is a marine fish of the family Labridae attaining a maximum length up to $35 \mathrm{~cm}$. This species occurs in the eastern Atlantic and the Mediterranean and Black seas (Quignard \& Pras 1986). It is not subject to targeted food fisheries. However, it is not rare to find it as a by-catch of fisheries focused on other species and its catches contribute significantly to recreational angling and spearfishing activities (Gordoa et al. 2000).

The peacock wrasse is found mainly on reefs and shallow coastal areas. Males are territorial and conspicuous male nuptial colouration and courtship have been observed (Costello 1991). The spawning season begins in April and ends in late June (Warner \& Lejeune 1985). Planktonic larval duration ranges from 9 to 13 days and settlement takes place from early May onwards (Raventos \& Macpherson 2001). Genetic studies are scarce and have relied mainly on mitochondrial DNA (mtDNA) to infer phylogenetic relationships within Labrids (Hanel et al. 2002). With the aim of estimating genetic variability at the nuclear level, here we report eight new polymorphic microsatellite DNA loci for the peacock wrasse.

An enriched genomic library was constructed following the methods of Glenn (2000) available at www.uga.edu/

Correspondence: Ciro Rico, Estación Biológica Doñana (CSIC), Av. Ma. Luisa S/N, 41013 Sevilla, Spain. Fax: (34) 954-621125; E-mail: ciro@ebd.csic.es
srel/DNA_Lab/protocols.htm, with modifications to the protocol as detailed in the succeeding text. Approximately $10 \mu \mathrm{g}$ of high molecular weight DNA of 10 individuals from Blanes (Western Mediterranean) was isolated by phenolchloroform extraction followed by ethanol precipitation (Sambrook et al. 1989). DNA extractions were performed from pectoral fin tissue, RNase treatment was applied where required and recovered DNA was diluted to $\sim 200 \mathrm{ng} / \mu \mathrm{L}$ final concentration. The genomic DNA was simultaneously digested with RsaI restriction enzyme and ligated to doublestranded linker-adapted primers (Hamilton et al. 1999). Restricted-ligated DNA fragments were amplified with linker-adapted primers and hybridized with a biotinylated probe mixture consisting of $(\mathrm{GT})_{10}$ and (GATA $)_{10}(\mathrm{CT})_{10}$ at $10 \mu \mathrm{m}$ each. DNA fragments with repetitive sequences were selectively captured by streptavidin-coated Dynabeads (Oxoid) and separated by a magnetic field. DNA was eluted in $\mathrm{dH}_{2} \mathrm{O}$ from the bead probes and concentrated by vacuum centrifugation to a final concentration of $\sim 100 \mathrm{ng} /$ $\mu \mathrm{L}$. DNA was then reamplified by polymerase chain reaction (PCR) using linker-adapted primers. Subsequent ligation of enriched/recovered DNA into a cloning vector was carried out using a TOPO TA cloning kit (Invitrogen) following the manufacturer's protocol.

More than 180 positive clones were obtained. All clones were sequenced and checked for inserts using ABI PRISM BigDye Terminator Cycle kit (Applied Biosystems) and 
Table 1 Characterization of eight peacock wrasse (Symphodus tinca) microsatellite loci. GenBank Accession no., locus name, repeat motif, fluorescent dye-primer sequence, number of alleles, allele size range, $H_{O}$, observed heterozygosity; $H_{E}$, expected heterozygosity under Hardy-Weinberg equilibrium; $\mathrm{F}_{\mathrm{IS}}$, inbreeding coefficient, $* \mathrm{P}<0.05$

\begin{tabular}{|c|c|c|c|c|c|c|c|c|}
\hline $\begin{array}{l}\text { GenBank } \\
\text { Accession no. }\end{array}$ & Locus & Repeat motif & Primer sequences $\left(5^{\prime}-3^{\prime}\right)$ & $\begin{array}{l}\text { No. of } \\
\text { alleles }\end{array}$ & $\begin{array}{l}\text { Allele } \\
\text { size (bp) }\end{array}$ & $\mathrm{H}_{\mathrm{O}}$ & $\mathrm{H}_{\mathrm{E}}$ & $\mathrm{F}_{\text {IS }}$ \\
\hline DQ324538 & Stin155 & $(\mathrm{GA})_{11}$ & $\begin{array}{l}\text { F: FAM-GAGGCAAACAAGTATTTTCA } \\
\text { R: AGGGACTGTGTTCTTGATG }\end{array}$ & 11 & $138-168$ & 0.8611 & 0.8798 & 0.054 \\
\hline DQ324537 & Stin287 & $(\mathrm{AC})_{6} \mathrm{GC}(\mathrm{AC})_{9}$ & $\begin{array}{l}\text { F: FAM-AGCAGGTTCAATAAACACA } \\
\text { R: GGGTGCTCAAGGTAATTGT }\end{array}$ & 9 & $275-297$ & 0.8055 & 0.8047 & 0.001 \\
\hline DQ324543 & Stin368 & $(\mathrm{AC})_{22}$ & $\begin{array}{l}\text { F: FAM-TCTGGCAGCCTTAGTCCTC } \\
\text { R: GAGCGTCTTCAGAAGGACA }\end{array}$ & 17 & $336-368$ & 0.7500 & 0.8873 & $0.247^{*}$ \\
\hline DQ324540 & Stin143 & $(\mathrm{AC})_{4} \mathrm{G}(\mathrm{AC})_{14}$ & $\begin{array}{l}\text { F: HEX-TGCAAGCAGAGTCTCAAACCC } \\
\text { R: ATTTAACAGCTTGCTTGG }\end{array}$ & 11 & $120-141$ & 0.9166 & 0.8924 & -0.027 \\
\hline DQ324542 & Stin222 & $(\mathrm{TG})_{9} \mathrm{C}(\mathrm{TG})_{17}$ & $\begin{array}{l}\text { F: HEX-CCCGTGATAGATGAGGAG } \\
\text { R: GGTGCTCCTGTGATATCT }\end{array}$ & 11 & $206-231$ & 0.7777 & 0.8321 & 0.159 \\
\hline DQ324539 & Stin336 & $(\mathrm{CA})_{36}$ & $\begin{array}{l}\text { F: HEX-GCTGGAAGAATAGAACATTC } \\
\text { R: TTTTTTTGCAAGCTTTTAGT }\end{array}$ & 13 & $321-365$ & 0.7714 & 0.8567 & 0.191 \\
\hline DQ324541 & Stin245 & $(\mathrm{GATA})_{30}$ & $\begin{array}{l}\text { F: NED-TAGCCCCGCCCCCTAAAAA } \\
\text { R: TGCTACTGGATGGCGCTGAA }\end{array}$ & 12 & $218-314$ & 0.8463 & 0.8961 & 0.084 \\
\hline DQ324536 & Stin138 & $(\mathrm{C})_{16}(\mathrm{CA})_{11}$ & $\begin{array}{l}\text { F: NED-GCGTTTTTACGTCATGTTTTT } \\
\text { R: AGGTATGTGTCCGCTTTT }\end{array}$ & 15 & $127-165$ & 0.6571 & 0.9155 & $0.424 *$ \\
\hline
\end{tabular}

resolved on an ABI 3100 Genetic Analyser (Applied Biosystems). PCR primers were designed using oligo 6.4 software. PCRs were performed in $25 \mu \mathrm{L}$ total volume, which includes $50 \mathrm{ng}$ of DNA, $1 \mathrm{~mm}$ of $\mathrm{MgCl}_{2}, 0.75 \mu \mathrm{m}$ of forward and reverse universal M13 primers, $200 \mu \mathrm{m}$ dNTP's, 1Xreaction buffer [75 mm Tris-Hcl, $20 \mathrm{~mm}$ $\left(\mathrm{NH}_{4}\right)_{2} \mathrm{SO}_{4}$ ] and $0.5 \mathrm{U}$ Taq polimerase (BIOTAQ). Reaction conditions were as follows: an initial denaturation step of $5 \mathrm{~min}$ at $95{ }^{\circ} \mathrm{C}, 30$ cycles consisting of $30 \mathrm{~s}$ at $92{ }^{\circ} \mathrm{C}, 30 \mathrm{~s}$ at $55^{\circ} \mathrm{C}$ annealing temperature and $30 \mathrm{~s}$ at $72{ }^{\circ} \mathrm{C}$. Individuals were genotyped by assessing allele size on an ABI 3100 Genetic Analyser (Applied Biosystems) using forward primers labelled with FAM, HEX (Sigma) and NED (Applied Biosystems). Allele scoring was carried out using genemapper version 3.5 software (Applied Biosystems).

Microsatellite variability was tested in 35 individuals from Blanes. Observed and expected heterozygosities as well as deviations from Hardy-Weinberg expectations were calculated using arlequin (Schneider et al. 2000). The number of alleles per locus and allele size range were estimated using fstat version 2.9. (Goudet 1995). All loci were polymorphic, the number of alleles per locus, expected and observed heterozygosities are listed in Table 1. There was no evidence of linkage disequilibrium between locus pairs. Two loci showed significant departures from Hardy-Weinberg equilibrium. This could be due to segregation of null alleles or population subdivision. With the present data set, we cannot distinguish conclusively between these alternatives, but the likeliest explanation is presence of null alleles segregating at high frequencies.
Nonetheless, these results suggest that most of the loci characterized could be useful for most population genetics applications.

\section{Acknowledgements}

This work was funded in part by the Mexican Council for Science and Technology CONACYT and Junta de Andalucia Ref. 2003X880_1.

\section{References}

Costello M (1991) Review of the biology of wrasse (Pisces: Labirdae) in Northern Europe. Progress in Underwater Science, $16,29-51$.

Glenn TC, Cary T, Dust M, Hauswaldt S, Prince K, Clifton R, Shute I (2000) Microsatellite Isolation. http:/www.uga.edu/srel/DNA_ Lab/protocols.htm

Gordoa A, Moli B, Raventos N (2000) Growth performance of four wrasse species on the north-western Mediterranean coast. Fisheries Research, 45, 43-50.

Goudet J (1995) fstat (2.9.3) a program for IBM compatible PCs to calculate Weir and Cockerman's (1984) estimators of F-statistics. Journal of Heredity, 86, 485-486.

Hamilton MB, Pincus EL, Di Fiore A, Flesher RC (1999) Universal linker and ligation procedures for construction of genomic DNA libraries enriched for microsatellites. BioTechniques, 27, 500-507.

Hanel R, Westneat MW, Sturmbauer C (2002) Phylogenetic relationships, evolution of broodcare behavior and geographic speciation in the wrasse tribe labrini. Journal of Molecular Evolution, 55, 776-789.

Quignard DP, Pras A (1986) Labridae. In: Fishes of the North-Eastern Atlantic and the Mediterranean (eds Whitehead PJP, Bauchot ML, Hureau JC, Nielsen J, Tortonese E), pp. 919-942. UNESCO, Paris. 
Raventos N, Macpherson E (2001) Planktonic larval duration and settlement marks on the otoliths of Mediterranean littoral fishes. Marine Biology, 138, 1115-1120.

Sambrook J, Fritsch EF, Maniatis T (1989) Molecular Cloning: a Laboratory Manual, 2nd edn. Cold Spring Harbor Laboratory Press, New York.
Schneider S, Roessli D, Excoffier L (2000) ARLEQUIN (version 2.000): a software for population genetics data analysis. Genetic and Biometry Laboratory, University of Geneva, Switzerland.

Warner RR, Lejeune P (1985) Sex change limited by parental care: a test using four Mediterranean labrid fishes, genus Symphodus. Marine Biology, 71, 203-208. 